\title{
Education for Road Safety: What is the State of Affairs in Three Groups of Vulnerable Road Users in Spain?
}

\author{
Francisco Alonso ${ }^{1}$, Cristina Esteban ${ }^{1}$, Mireia Faus ${ }^{1}$, Sergio A. Useche ${ }^{1,2}$ \\ ${ }^{1}$ DATS (Development and Advising in Traffic Safety) Research Group, INTRAS (Research Institute on Traffic \\ and Road Safety), University of Valencia. Carrer del Serpis 29, 3rd Floor, DATS. 46022. Valencia, Spain \\ ${ }^{2}$ Faculty of Psychology, University of Valencia. Av. Blasco Ibáñez 21. Valencia, 46010, Spain
}

\begin{abstract}
RSE (Road Safety Education) is well recognized as a reliable predictor of future safety and health outcomes. However, most countries have been slow to develop it, which has contributed to the sensitivity of the situation, as traffic accidents continue to be a major concern for community health. This paper aims to describe and compare key variables related to the RSE among three critical segments of the population, using the data provided by: $477 \mathrm{high}$ school students, 843 university students and 476 older adults. Differential coverage rates were found. Perceived quality, aroused interest and attributed utility for RSE interventions were also compared among groups, finding substantial differences among them in terms of these three aspects of the intervention. Although coverage of RSE-related programs has grown considerably during the last years, substantial difficulties are still evident.
\end{abstract}

DOI: 10.18421/TEM104-03

https://doi.org/10.18421/TEM104-03

Corresponding author: Sergio A. Useche,

DATS (Development and Advising in Traffic Safety) Research Group, INTRAS (Research Institute on Traffic and Road Safety), University of Valencia. Carrer del Serpis 29, 3rd Floor, DATS. 46022. Valencia, Spain.

Faculty of Psychology, University of Valencia. Av. Blasco Ibáñez 21. Valencia, 46010, Spain.

Email: sergio.useche@uv.es

Received: 04 June 2021.

Revised: 10 August 2021.

Accepted: 17 August 2021.

Published: 26 November 2021.

(c))BY-NC-ND (C) 2021 Sergio A. Useche et al; published by UIKTEN. This work is licensed under the Creative Commons Attribution-NonCommercial-NoDerivs 4.0 License.

The article is published with Open Access at www.temjournal.com
Keywords - Road Safety Education; coverage; quality; spanish population; vulnerable road users

\section{Introduction}

Road Safety Education (or Education for Road Safety), in terms of learning, performance and safety outcomes of every road user, is something that lasts from birth to death, and it is considered a reliable determinant of the overall road health and road safety behaviours of a community. Therefore, we can state that -a priori- road safety education is an indisputable need for the welfare and integrity of the entire population, i.e., from childhood to late adulthood [1].

Keeping in mind that there is a difference between the concepts of road safety education and training, it is necessary to clarify that, unlike the "road training", which is normally focused on drivers, road safety education affects all road users (e.g., passenger, pedestrian, driver, etc.). In contrast, training only affects the user who is a driver. In this sense, road safety education extends throughout the lifetime and must be present in all developmental scenarios of the individual, including the educational system [2]. In fact, one of the inherent characteristics of road safety education is that it is a continuous and noninterrupted process [3]. A previous set of studies on the Spanish population has found that, among the characteristics that we can include in the current practice of road safety education, the implementation of this subject should be considered "almost deficient", with a clear lack of application both for students and for the rest of the population, that does not correspond to the theoretical paradigm of road safety throughout life usually conceived by health promotors [2]. Moreover, methodological guidance and planning are usually unspecific, and sometimes nonexistent. In other words, it is difficult to talk about the historical existence of a systematic evolution, consistency and regularity in the development of Spanish road safety education. This marked deficit, evident in the coverage and quality of 
road safety education in Spain, is one of the major indicators that affect and predict the appearance of unsafe behaviours in different groups of population. In recent studies that have investigated the rate of coverage and adequacy of road safety education, it was found that, for instance, there are still marked shortages of them in the school system, especially in small towns and rural areas.

Recent studies have analyzed road safety education in students of superior educational cycles, showing that the coverage provided by universities in terms of RSE teaching is very low. This research also states that it is essential to elaborate more efficient strategies to prevent university students' risky attitudes, especially in the case of profiles that are most vulnerable to risk-taking, such as (in the case of university students), males between 18-25 years of age -young adults- without previous involvement in road safety education experiences [4].

Meanwhile, in recent years educational institutions have shown steady progress regarding the interest of bringing higher and better road safety education to their students. However, considering various often existing constraints (e.g. lack of resources, absence of programs, deficit of qualified people to teach the subject), this process has been experiencing serious difficulties in reaching the needed coverage within the numerous student population. This, plus the fact that childhood and adolescence are considered the most critical life stages for learning and implementing road safety education [5], together with the lack of it, represents a problem that threatens the life and integrity of young people [6].

Another empirical study conducted in Spain showed the ultimate necessity of road safety education and the integration of key interested parties in it, such as the family and the educational system aimed at encouraging safe attitudes, actions, and outcomes. Also, parents' actions and circumstances have a significant impact on their children's road safety education because the children take the example of them, and sometimes it is the worst example to follow. This evidence supports the idea that it is important to develop a well-organized road safety education instructional system.

In the case of young adults, it is known that this is the stage in which a greater adaptation/disadaptation to processes such as driving and coping with different road-risk factors take place. Especially in this age group, issues such as alcohol and drug consumption [7], speeding [8] risk exposure [9] (related to a greater use of roads and means of transport), risk perception [10] and attitudes towards road safety [11] are key issues to consider in terms of education for road safety.
As for elderly people, in terms of accident rates, the proportion of deaths in traffic accidents was approximately twice their proportion in the population between the years 2013 - 2015 [12]. Statistics in other countries, such as the United States, also show that these proportions are consistent. Furthermore, according to recent studies, people over 75 usually suffer more deaths from traffic accidents than any other group of population, except those under 25 years [13]. Senior drivers, for example, tend to present (even if they usually have more experience as road users) higher accident rates than other drivers, except teenagers. The mortality rate for drivers over 75 years is around $500 \%$ the average of the rest of the population, and their rate of injuries or wounds is two times superior compared to other age groups.

\subsection{The Importance of Quality and Assessment in Road Safety Education}

The evaluation of any intervention or action in road safety education is essential, i.e., assessing tools and mechanisms to understand its impact and the experience of the beneficiaries thereof, in order to demonstrate whether the implemented interventions are effective in improving road safety, in order to demonstrate the success and impact of an intervention and to establish what can be improved in each of them.

The evaluation of the results of the interventions is also an essential part of a good intervention [5]. There are many reasons to praise the evaluation of educational intervention in road safety: it determines the strengths and weaknesses of an intervention or a set of them; it allows to study and reflect on the progress of road safety education; it determines how much knowledge and practice of road safety the population acquires, and it allows us to learn from the successes and mistakes that have occurred. Furthermore, assessment processes are useful to several specific aspects, such as: identifying ways to improve the intervention; determining whether the intervention is effective; establishing why it is effective or ineffective and making decisions about going on with the program or modifying and improving it. Regardless of its emphasis, the concept of intervention (including the field of Road Safety Education), could be defined as any action (activity, program, set of activities, etc.) designed to achieve specific results in a target group [2].

\subsection{Study Framework}

The linkages between road safety education and their subsequent effects on traffic safety outcomes are the most relevant theoretical underpinning for this study. Given the current multidimensional 
apporach of road safety nowadays, the amount of RSE-related factors to consider in this study has been based on the Useche's PARK model, where perception of road risks, attitudes, and rule knowledge play a crucial role as core road safety education-based skills [14]. Other studies have also endorsed their closer relationship to individuals' well-being and their mental health outcomes [1] [3].

In this perspective, road safety and health should be approached holistically, taking into account many spheres but giving a major role to psychosocial and educational issues, as Road Safety Education has shown to be an interesting process to consider in road safety research, given that it takes place along the whole lifecycle of individuals [5].

Furthermore, it is critical to comprehend the aspects that influence children's learning of road safety in order to prevent future risky behaviours and traffic crashes, as well as to enhance awareness and risk perception among youngsters. As a result, this paper was written as part of a macro-research project on road safety performed in Spain by the INTRAS University of Valencia during the last three years.

\subsection{Objective}

The core aim of this research was describing and comparing the coverage, participation and quality perceived in programs or actions related to road safety education (RSE) in three population groups that may be considered of critical interest, in order to promote safe behavior and training on issues related to road safety through different scenarios of institutional performance.

\section{Methods and Materials}

\subsection{Sample}

A sample of 1796 people from different regions around the Spanish territory was used. The total group of participants was subdivided according to the shape of three groups of interest, as follows: 1) the first group of students attending High School and/or "Professional" or Vocational Formation cycles, composed of $n=477$ subjects, with a mean age of $M=17.19 \quad(S D=2.40)$ years; 2) a group of $n=843$ university students, with an age of $M=22.56$ $(S D=4.29)$; and 3) a group of $n=476$ older adults with a mean age of $M=73.16(S D=6.76)$ years.

\subsection{Design, Procedure and Instrument}

For this cross-sectional study, a questionnaire was designed with the purpose of studying the factors related to participation in road safety education. The sample was designed and obtained through a convenience sampling process in different a) school centers (in the case of high school students), b) higher education institutions (university students), and c) older adults' centers of different cities of Spain. Regarding data collection method, the whole samples of high school students and older adults were collected through personal application within their respective centers. For the case of university students, almost $80 \%$ of them completed the survey using a web-based survey, while the remaining $20 \%$ completed it in person in the classroom using a paper version of the same questionnaire. The global response rate was approximately $95 \%$ of total surveys or invitations to participate in the case of the web-based questionnaires delivered.

The survey was performed while maintaining the participants' anonymity at all times and underlining existing data privacy rules and the totally anonymous character of the data collected that should be only used for research purposes. Considering the minimum level of risk implied to our partakers as a consequence of their involvement in the study, a consent declaration was considered by the research ethics committee as not necessary for this type of investigation. However, both the study aims and dynamics, and the need of answering all questions honestly was underlined, as well as the fact that there were no incorrect or right answers.

The instrument aimed at covering three different scenarios, and it asked, among other issues, whether the participants had received any training or education in Road Safety in these scenarios. It also asked about specific factors related to satisfaction with the received intervention, about the quality of the program and the usefulness perceived in this type of intervention, as well as about the topic of road safety education.

\subsection{Statistical Analysis (Data Processing)}

Initially, we carried out descriptive analyses to meet the coverage rates of road safety education in each group; subsequently, the indicators related to road safety education interventions were determined through descriptive and frequency analyses. Finally, after having conducted statistical tests for normality and having tested fundamental parameters, One-way analysis of variance (ANOVA) was used to compare the perception of impact and quality variables of road safety education among the three reference groups. We carried out data analysis by Statistical Package for the Social Sciences (IBM SPSS), version 22.0.

\subsection{Ethics}

For this research, both the study setting and protocols were evaluated by the Research Ethics 
Committee for Social Science in Health (INTRAS University of Valencia). The positive ethics assessment certified that the research design and procedures complied with the general ethical principles, and was consistent with the Declaration of Helsinki. There, it issued a favourable opinion to carry out the study in Spain (IRB protocol HE0002020919).

\section{Results}

\subsection{Coverage and Essential Measures Related to Road Safety Education}

Overall, and regarding the coverage in road safety education actions and/or programs, a set of differential results was found, very particular for each one of the referenced groups. In addition, relatively high levels of satisfaction with the provided activities were observed in the sample. As a first step to understanding the dynamics in each one of these three segments of the population, the percentages of coverage, participation and satisfaction will be separately presented below.

\subsection{Scholar Students (High School)}

The entire sample of participants within this group are currently attending educational institutions (high/middle school), the reason why the data collection was conducted in the classroom. As shown in Table 1., $60.2 \%$ of this group reported having received some type of program, action or activity on RSE in their school or educational institution.

Regarding the specific variables (satisfaction and complementary indicators) related to the institutionally delivered activities of road safety education, it was found that assessment results reflect a favourable view of these actions in general (see Table 1.).

Table 1. Issues related to participation in, and quality of, interventions of road safety education among high school students

\begin{tabular}{|c|c|c|c|}
\hline $\begin{array}{c}\text { Have } \\
\text { participated in } \\
\text { RSE activities? } \\
(n=462)\end{array}$ & Frequency & 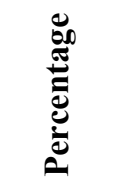 & 를 \\
\hline No & 184 & $38,6 \%$ & $39,8 \%$ \\
\hline Yes & 278 & $58,3 \%$ & $60,2 \%$ \\
\hline Total & 462 & $96,9 \%$ & $100 \%$ \\
\hline $\begin{array}{c}\text { Specific issues } \\
(n=278)\end{array}$ & Question & Yes & No \\
\hline Organization & $\begin{array}{l}\text { Was that activity } \\
\text { well organized? }\end{array}$ & $92,6 \%$ & $7,4 \%$ \\
\hline
\end{tabular}

\begin{tabular}{|c|c|c|c|}
\hline \multirow[b]{3}{*}{ Aroused interest } & $\begin{array}{l}\text { Were the topics } \\
\text { interesting? }\end{array}$ & $85,1 \%$ & $14,9 \%$ \\
\hline & $\begin{array}{l}\text { Did you enjoy that } \\
\text { activity in general? }\end{array}$ & $85,8 \%$ & $14,2 \%$ \\
\hline & $\begin{array}{l}\text { Would you like to } \\
\text { re-engage in an } \\
\text { activity similar to } \\
\text { the one that was } \\
\text { organized in your } \\
\text { school? }\end{array}$ & $78,0 \%$ & $22,0 \%$ \\
\hline $\begin{array}{l}\text { Perceived } \\
\text { usefulness }\end{array}$ & $\begin{array}{l}\text { Is what you } \\
\text { learned useful for } \\
\text { you? }\end{array}$ & $87,1 \%$ & $12,9 \%$ \\
\hline $\begin{array}{c}\text { Quality of } \\
\text { implementation }\end{array}$ & $\begin{array}{l}\text { Did you like the } \\
\text { person who } \\
\text { conducted the } \\
\text { activity (police, } \\
\text { teacher, doctor...)? }\end{array}$ & $83,5 \%$ & $16,5 \%$ \\
\hline Sharing & $\begin{array}{l}\text { Did you tell } \\
\text { someone about the } \\
\text { activity? }\end{array}$ & $71,2 \%$ & $28,8 \%$ \\
\hline $\begin{array}{c}\text { Previous } \\
\text { participation in } \\
\text { RSE actions }\end{array}$ & $\begin{array}{l}\text { Had you ever } \\
\text { participated in } \\
\text { some other activity } \\
\text { on traffic inside or } \\
\text { outside the center } \\
\text { before? }\end{array}$ & $51,4 \%$ & $48,6 \%$ \\
\hline
\end{tabular}

Specifically, $92.6 \%$ of the respondents from this group considered that activities on road safety education had been well-organized; $85.1 \%$ believed that the issues discussed in these activities were interesting, and $87.1 \%$ reported that the learned contents proved useful for them. About the conduction of the activity, $83.5 \%$ of them said that they liked the person who made or directed that activity; $71.2 \%$ shared the fact of having participated with their parents, and $78 \%$ believed that they would participate in a similar activity. Finally, it was found that $51.4 \%$ of these students had previously participated in some other activity related to this issue outside their school.

\subsection{University Students}

Of the total of participants in this group, 97.2\% (819 of them) were currently attending university or higher education institutions. $97.7 \%$ were studying a bachelor's degree; .9\% are attending a master's degree, and $1.5 \%$ are currently attending a doctoral program.

It was found that, from the total of university students who participated in this study, only $5.1 \%$ of them reported having received some action, activity or program related to road safety education at the university or equivalent institution (see Table 2.). 
Table 2. Issues related to participation in, and quality of interventions on road safety education among university students

\begin{tabular}{|c|c|c|c|}
\hline $\begin{array}{c}\text { Have } \\
\text { participated } \\
\text { in RSE } \\
\text { activities? } \\
(n=819)\end{array}$ & Frequency & 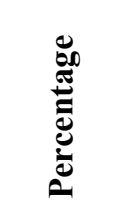 & స \\
\hline No & 777 & $94.9 \%$ & $94.9 \%$ \\
\hline Yes & 42 & $5.1 \%$ & $5.1 \%$ \\
\hline Total & 819 & $100 \%$ & $100 \%$ \\
\hline $\begin{array}{c}\text { Specific issues } \\
(n=42)\end{array}$ & Question & Yes & No \\
\hline Organization & $\begin{array}{l}\text { Was that activity well } \\
\text { organized? }\end{array}$ & $95.2 \%$ & $4.8 \%$ \\
\hline \multirow{3}{*}{$\begin{array}{l}\text { Aroused } \\
\text { interest }\end{array}$} & $\begin{array}{l}\text { Were the topics } \\
\text { interesting? }\end{array}$ & $90.5 \%$ & $9.5 \%$ \\
\hline & $\begin{array}{l}\text { Did you enjoy that activity } \\
\text { in general? }\end{array}$ & $90.5 \%$ & $9.5 \%$ \\
\hline & $\begin{array}{l}\text { Would you like to re- } \\
\text { engage in an activity } \\
\text { similar to the one that was } \\
\text { organized in your school? }\end{array}$ & $85.7 \%$ & $14.3 \%$ \\
\hline $\begin{array}{l}\text { Perceived } \\
\text { usefulness }\end{array}$ & $\begin{array}{l}\text { Is what you learned useful } \\
\text { for you? }\end{array}$ & $95.2 \%$ & $4.8 \%$ \\
\hline $\begin{array}{c}\text { Quality of } \\
\text { implementatio } \\
\mathrm{n}\end{array}$ & $\begin{array}{l}\text { Did you like the person } \\
\text { who conducted the } \\
\text { activity? }\end{array}$ & $92.9 \%$ & $7.1 \%$ \\
\hline Sharing & $\begin{array}{l}\text { Did you tell someone } \\
\text { about the activity? }\end{array}$ & $73.8 \%$ & $26.2 \%$ \\
\hline $\begin{array}{c}\text { Previous } \\
\text { participation } \\
\text { in RSE actions }\end{array}$ & $\begin{array}{l}\text { Had you ever participated } \\
\text { in some other activity on } \\
\text { traffic inside or outside the } \\
\text { center before? }\end{array}$ & $73.8 \%$ & $26.2 \%$ \\
\hline
\end{tabular}

Similarly, when evaluating the aspects related to the quality of the received interventions among students who had participated in them, interesting facts were found, as shown in Table 2.

Specifically, $95.2 \%$ of the respondents from this sample of university students qualified road safety education-related activities as well-organized; $90.5 \%$ said that the issues involved in the activities were interesting, and $95.2 \%$ believed that what they learned was useful in both their life and in their potential road behaviour. As for the conduction of the activity, $83.5 \%$ said that they liked the person who conducted/directed the activity; $73.8 \%$ shared the experience or its contents with someone else, and $85.2 \%$ believed they would participate in other activities, very similar to the one previously received. Finally, it was found that $73.8 \%$ of students in universities had previously participated in some other activity related to road safety education outside their university (see Table 2.).

\subsection{Seniors (older adults)}

From the total of 476 elderly adults who participated in this study, only $24.1 \%$ (114 of them) are currently attending a senior or pensioners' centre (see Table 3.). The rest of them attend other sorts of places (e.g., social centres, governmental programs, support groups, health institutions with social programs), where the RSE can be taught, or has no affiliation with any centre. Therefore, only this fragment of the sample was considered in order to study, in greater detail, the specific factors related to the delivery of these initiatives or programs on road safety education.

Table 3. shows the fixed satisfaction rates regarding specific items of the programs on Road Safety Education which had been taught to elderly adults. Specifically, $92.1 \%$ of respondents from this group considered that this kind of activity had been well organized; $88.9 \%$ believed that the issues discussed along the activities were interesting, and $98 \%$ considered that the learned contents were useful for their lives.

Table 3. Issues related to participation in, and quality of interventions on road safety education in seniors (older adults)

\begin{tabular}{|c|c|c|c|}
\hline $\begin{array}{c}\text { Have } \\
\text { participated in } \\
\text { RSE activities? } \\
(n=114)\end{array}$ & Frequency & 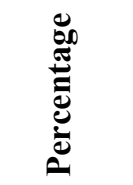 & : \\
\hline No & 101 & $88.6 \%$ & $88.6 \%$ \\
\hline Yes & 13 & $11.4 \%$ & $11.4 \%$ \\
\hline Total & 114 & $100 \%$ & $100 \%$ \\
\hline $\begin{array}{c}\text { Specific issues } \\
(\mathrm{n}=13)\end{array}$ & Question & Yes & No \\
\hline Organization & $\begin{array}{l}\text { Was that activity well } \\
\text { organized? }\end{array}$ & $92.1 \%$ & $7.9 \%$ \\
\hline \multirow{3}{*}{$\begin{array}{l}\text { Aroused } \\
\text { interest }\end{array}$} & $\begin{array}{l}\text { Were the topics } \\
\text { interesting? }\end{array}$ & $88.9 \%$ & $\begin{array}{l}11.1 \\
\%\end{array}$ \\
\hline & $\begin{array}{l}\text { Did you enjoy that } \\
\text { activity in general? }\end{array}$ & $98.2 \%$ & $1.8 \%$ \\
\hline & $\begin{array}{l}\text { Would you like to re- } \\
\text { engage in an activity } \\
\text { similar to the one that } \\
\text { was organized in your } \\
\text { center? }\end{array}$ & $88.9 \%$ & $\begin{array}{l}11.1 \\
\%\end{array}$ \\
\hline $\begin{array}{l}\text { Perceived } \\
\text { usefulness }\end{array}$ & $\begin{array}{l}\text { Is what you learned } \\
\text { useful for you? }\end{array}$ & $98.0 \%$ & $2.0 \%$ \\
\hline $\begin{array}{c}\text { Quality of } \\
\text { implementation }\end{array}$ & $\begin{array}{l}\text { Did you like the person } \\
\text { who conducted the } \\
\text { activity? }\end{array}$ & $88.9 \%$ & $\begin{array}{l}11.1 \\
\%\end{array}$ \\
\hline Sharing & $\begin{array}{l}\text { Did you tell someone } \\
\text { about the activity? }\end{array}$ & $89.0 \%$ & $\begin{array}{l}11.0 \\
\%\end{array}$ \\
\hline
\end{tabular}




\begin{tabular}{|c|c|c|c|}
\hline $\begin{array}{c}\text { Previous } \\
\text { participation in } \\
\text { RSE actions }\end{array}$ & $\begin{array}{l}\text { Had you ever } \\
\text { participated in some } \\
\text { other related activity } \\
\text { before inside or outside } \\
\text { the center before? }\end{array}$ & $97.8 \%$ & $2.2 \%$ \\
\hline
\end{tabular}

Specifically, regarding the teaching process of the activity or program, $88.9 \%$ said that they liked the person who directed the activity. Moreover, $89 \%$ of older adults participating in these activities said that they had participated (or shared the contents) with other people, and $88.9 \%$ would like to receive a similar intervention, or some related initiative on the same topic.

Finally, it was found that $97.8 \%$ of older adults had previously participated in some activity related to the RSE outside the center they were attending. It is worth noting that this high rate of coverage may be related to the age of the participants, taking into account that age and received RSE levels are correlated.

\subsection{Comparative Analyses}

Performing a comparative analysis of the institutional coverage (activities received in middle and high educational institutions or adult centers), this was determined to be significantly different for each one of the groups. Figure 1. presents the graphical percentages of institutional coverage and participation (regarding the currently attended institution) showed by each group.

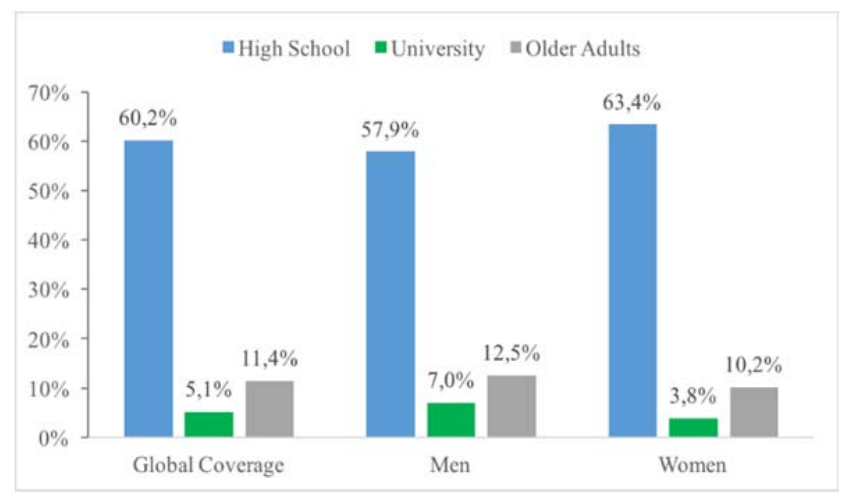

Figure 1. Comparison of institutional coverage rates (percentages) in Road Safety Education between the three reference groups

The highest rate found corresponds to the group of high school students, with $60.2 \%$ of participants having been involved in some activity of this type in their educational institution. For the group of university students, a comparatively much lower rate was found, with only $5.1 \%$ of coverage of such interventions in universities. Meanwhile, only $11.4 \%$ of older people attending public or private centres have received such teaching there.
By carrying out the contrasts (mean comparisons) between the three reference groups in variables related to the quality of interventions in road safety education (among participants who have been beneficiaries of such programs or activities) through One-way analysis of variance (ANOVA), it was found that there are no significant differences in the perception of proper organization of interventions when comparing the continuous (not categorical) rate of satisfaction, being the trend averagely higher in young adults (university students) and slightly lower for older adults. ANOVA results are depicted in detail in Table 4.

Table 4. Comparison of means in variables related to the implementation of road safety education between the three groups (means and ANOVA results)

\begin{tabular}{|c|c|c|c|c|}
\hline \multirow{2}{*}{ Variable } & \multicolumn{3}{|c|}{ Means } & \multirow{2}{*}{ Sig. } \\
\hline & Scholars & University & Senior & \\
\hline $\begin{array}{l}\text { Organization of } \\
\text { interventions }\end{array}$ & .926 & .952 & .921 & .069 \\
\hline Aroused interest & .851 & .905 & .894 & $* *$ \\
\hline $\begin{array}{l}\text { Perceived } \\
\text { usefulness }\end{array}$ & .871 & .952 & .980 & $* *$ \\
\hline $\begin{array}{l}\text { Quality of } \\
\text { implementation }\end{array}$ & .835 & .929 & .883 & $* *$ \\
\hline $\begin{array}{l}\text { Share activity } \\
\text { with others }\end{array}$ & .712 & .738 & .889 & $* *$ \\
\hline
\end{tabular}

** The difference is significant at the 0.01 level.

In the case of $a$ ) the interest generated towards road safety education through the intervention, and $b$ ) the perceived quality of the intervention, the average is significantly higher in the case of young adults, as shown in Table 4. Finally, older adults perceived interventions on road safety education as more useful for their life and mostly shared the knowledge acquired from interventions with others, with a significant statistical difference with the other two analyzed groups.

\section{Discussion}

Overall, this study found out that the coverage of actions and programs of road safety education (RSE) in Spain is, at first glance, still insufficient, as for factors that are defined as urgent to be intervened by the public health and educative policymakers, such as accident rates, gaps in terms of training, knowledge and evaluation of programs implemented for this purpose within public and private institutions [2]. This empirical approach indicates that although there are fairly high rates of satisfaction in the case of those who have participated in the mentioned activities, the coverage rates do not support the conclusion that road safety education for these groups is universal or meaningful [15], [16]. 
However, some data on specific groups allow comparing the obtained results with some theoretical and practical budgets, provided by different researches and by the implementation and evaluation of experiences on road safety education. Considering that all the three groups are highly vulnerable, as aforementioned, the status of the RSE within this population segments, and some relevant related facts and rates found, will be particularly discussed before integrating the obtained data.

\subsection{High School students}

In the case of Spanish students who are still attending middle/high school, although a $60.2 \%$ of coverage in actions aimed at road safety education has been found (six of each 10 students theoretically covered), it should be noted that this type of learning in middle/high school represents a late stage of basic education, probably not deep enough to properly develop all the required skills, attitudes and knowledge necessary to construct "safe" road users through the potential interventions provided by the educational system.

In this sense, we can say that coverage, although significantly higher than in the other groups that were part of this study, proves insufficient for what concerns the universe of population that it should cover, introducing the need for such interventions in the Spanish educational system. According to some previous relevant studies and developments in the area [15], institutions must ensure that in the formative stages of life -essentially the inclusion of the individuals during school education-, there is sufficient teaching, in quality and quantity of content, for the learning of safe attitudes, behaviours and knowledge, in order for students to positively take the role of road user throughout life [17].

However, evidence has shown that road safety education should go beyond the mere teaching of theoretical content in the classroom. Although classroom instructions result as useful to facilitate the theoretical learning of minimum content issues for road safety education among young people, some complementary and/or interactive scenarios (i.e., roadside training facilities) may potentiate, efficiently, the effect of interventions conducted in this area [18].

Another clear limitation, in addition to the ones mentioned above, is the lack of interference or integration of parents and caregivers within the educational system, including in the development of road safety education [19]. According to highly valued studies in this field, the insertion of parents in the road safety education of their children contributes to maximizing the learning opportunities, once steadily implemented the knowledge provided by the scholar system [20]. In this regard, it has been found that the active involvement of parents in road safety education of children and adolescents allows stimulating their perception of risk, safe habits for moving in traffic and more favourable attitudes towards road safety. This relational process should not to be limited, as it usually is, to accompaniment and/or supervision [21],[22]. Rather, it should involve behaviours observed in the family and microsocial behaviours, which constitute a fundamental part of the social learning of young individuals [23].

Another key issue that must be discussed for this group, finally, is the readability of road safety education interventions that are taught in the school system. According to some technical reports, the effects of evaluable programs are verifiable, considering factors such as its level of relevance/value, effectiveness, efficiency and duration [2]. However, and this is a limitation of this study, we often find some isolated actions or microinterventions, which have no proven or further support for their beneficiaries, and that are referred to as "programs" or "interventions", not necessarily being so, due to their low level of complexity, depth and/or systematic contents [24].

\subsection{University Students}

As for results obtained in the case of university students, it was found that they held the lowest coverage rate among the three studied groups. In practical terms, only one in twenty university students (+-5\%) have received any intervention and/or programs aimed at improving the formation in road safety within the educational institution. Given that one of the population segments with the greatest rates of traffic accidents is young adults, it is essential to raise this issue because of the high impact in road safety education that is necessary for this age group [25].

While universities have never been regarded for their ability to provide comprehensive road safety education, unlike the case of schools, the lack of coverage does not mean that the limited interventions that are now available are of poor quality or effectiveness. Recent analyses have indicated that strategies for the RSE at university, designed and structured for a target public with significantly advanced academic level and "higher" expectations, are programs with good rates of efficiency (e.g.) the acquisition and change of road safety attitudes, the development of safe road behavior and perception of risk [2]. In this sense, and based on the results found in this study, it can be said that the problem in this area is not merely coverage but the absence of integration between higher education institutions and 
priorities of public health within the education, as it is the case in road safety education.

Furthermore, according to some previous studies on the population of young adults, it can be stated that this is (for excellence) the last stage of greatest importance in the acquisition of elements of road safety education, which usually occurs through road training that takes place in driving schools [26]. In this regard, it should be noted that there is a clear need for the integration of young adults in road safety education prior to the start of their time as potential drivers, since this means an opportunity for the development of key elements of road safety, such as attitudes, perceptions and habits of safety and risk prevention as road users [27].

Early adulthood is statistically the stage where most of novice drivers begin to operate a vehicle, and driving school is often the first source of road safety education and training along their lives; some studies have been discussing novice drivers' road behaviour, evidencing great shortcomings in this area, even once the preparatory phase and the graduation from driving school are finished [26]. Without wishing to reduce the explanation of performance and safe or unsafe behaviour of young drivers to road safety education or advice received in educational centers, the importance of the RSE as a basic source of learning safe road behaviours has also been attributed to the influence of parents and family figures [19].

At the level of social environment participation in young adults' road safety education, it has been previously found that the most successful intervention programs in the area tend to keep in mind these social and psychological determinants, and, at the same time, to have higher rates of success and stability over time.

Also, it has been discovered that psychological variables are linked to a higher frequency of unsafe driving behaviours, which are associated with higher crash frequencies among young adults [24]. Previous reports have discussed the most effective schoolbased road safety instruction approaches among young road users. The findings show that, among the strategies with the most positive impact to this task, we need to include the social and community level, strengthen the promotion of road safety from educational institutions and the integration into this process of specialized trainers and coaches, which can normally be provided from driving schools and share their expertise, being these scenarios critical to the formation of good drivers and road users in general [2],[26].

\subsection{Seniors (Older adults)}

The elderly group presents a set of results that show a low coverage of educational activities in the field of traffic configuration and insufficient institutional strategies to improve road skills of older adults. The task of improving road safety in groups presenting an older age is linked to the recognition of their specific needs, as they are more prone to understand the elements of the road, and the psychophysical factors and attitudes towards road safety [28]. Also, accident rates in older adults raise the relevance of actions that foster both monitoring and continuity of road safety education [29].

There is no doubt that the wide imbalance of coverage in road safety education corresponds, in the case of older adults, to the generational change; previously, the RSE was not considered an important issue for political or social discussion, and much less for the educational system itself. Some studies have addressed the issue of continuity of training, and the RSE claims that this process does not have to be interrupted from one stage of life to another; on the contrary, it must be ensured that every subject of a community has coverage regardless of age, even though with emphasis on "prioritizing" the most vulnerable groups, such as the elderly [28],[29].

In terms of road safety education, providing coverage constitutes a comprehensive and complex process for what concerns the aging population and other similarly vulnerable groups. According to evidence, the biggest challenge with elderly people is not only to improve and/or "adapt" interventions, but to develop an institutional framework aimed at integrating resources and social approaches, which could capture the attention and the potential of this group in terms of road safety. The "best prevention" is training at the proper time, essentially when a population group has rates of road accidents (and severity of these accidents) which are as high as the one we have considered [26].

\subsection{Integrative Balance}

As a first approach derived from the analysis of the obtained data, plus a theoretical/practical approach based on the existing literature in the area, we found that, in the Spanish context, the coverage of road safety education is rather limited, if we consider the three analyzed reference groups separately. Although in theory the road safety education is an input that should be provided to all road users [5],[6], it is still widely focused on younger age groups, as it has been highlighted in the case of high school students and vocational training students.

Considering the differences observed between the three samples, and regarding the variables related to the implementation of road safety education in Spain, we found consistency in the perception that road safety education interventions are generally well organized $(M=0.933$ of a maximum of 1$)$, with no 
significant differences between groups. However, such interventions arouse more interest in university students or, i.e., young adults $(M=0.905)$, which in turn receive less coverage among the three groups. Also, they are the ones who receive better quality in implementation. Meanwhile, older adults are the ones who found the greater utility in road safety education $(M=0.980)$ and who tend to share this content with others who are road users too.

Finally, it is worth emphasizing even more on the need to develop institutional strategies for the promotion of educational coverage, and for the quality and evaluation of road safety educational programs, being these a process that certainly should be essential to the performance of the role of road user of every individual and, also, as a topic of discussion in the various fields of social reality [30]. In addition to this, some studies have considered the importance of developing a holistic approach to road safety education as part of sustainable development [31]. This issue, of course, implies the need to make road safety education policies cover education, social areas and, of course, public health.

\section{Conclusions}

Through this study, the need to elaborate a comprehensive and inclusive perspective to road safety education is strengthened through evidence, especially considering groups of the population with less actions of coverage in the education and training for road safety, such as in the case of the three groups addressed by this research.

Specifically, regarding the Spanish context, the coverage of road safety education is highly selective or, rather, reduced to the limited opportunities that formal teaching spaces, such as schools, offer. However, these needs (still unrealized) concern the entire population, especially the most vulnerable groups of road users.

Therefore, the further conclusion from the experience of this research is that the entire process of educating the general population on road safety should be strengthened and extended through the design, implementation and evaluation of road safety education in Spain.

\subsection{Limitations and Further Research}

Finally, we need to highlight some limitations of the present work, which include, first, that the method used for data collection was a self-report instrument, as observed in previous cross-sectional studies based on this method [32]. This implies that, even though the treatment of information was statistically accurate, the core variables of the study could potentially present some biases. Using self- reported data may lead to different types of biases, such as social desirability or lack of sincerity [32]. Also, other factors can have some influence on the responses provided by participants, such as, for instance, the participants' affectivity or opinion on the institutional belonging (whether positive or negative).

Moreover, we cannot forget the methodological difficulties implied in some variables that we have mentioned throughout the study, such as "program" or "action" applied to Road Safety Education, since there are different conceptions of what "program" means. Furthermore, many isolated and nonsystematic interventions tend to be presented to their beneficiaries as programs without fulfilling the basic criteria. It is necessary to develop a methodology that considers this distinction in future experiences. For what concerns any future research, we believe that the use of qualitative methods (for instance, interviews and focus groups) for collecting information could provide a better understanding of essential aspects, such as the subjective view and the participants' own experience with Road Safety Education, as well as their extensive comprehension of the phenomenon and suggested issues for the general improvement of programs.

\section{References}

[1]. Boot, W. R., Stothart, C., \& Charness, N. (2014). Improving the safety of aging road users: a minireview. Gerontology, 60(1), 90-96.

https://doi.org/10.1159/000354212

[2]. Alonso, F., Useche, S. A., Valle, E., Esteban, C., \& Gene-Morales, J. (2021). Could Road Safety Education (RSE) Help Parents Protect Children? Examining Their Driving Crashes with Children on Board. International Journal of Environmental Research and Public Health, 18(7), 3611. https://doi.org/10.3390/ijerph18073611

[3]. SAAQ. (2012). Road Safety Education Program. Québec: Société de l'assurance automobile du Québec. Retrieved from:

https://saaq.gouv.qc.ca/fileadmin/documents/publicatio ns/road-safety-education-program.pdf [accessed: 05 May 2021].

[4]. Olumide, A. O., \& Owoaje, E. T. (2016). Effect of a road safety education intervention on road safety knowledge of university drivers in Ibadan, Nigeria. Annals of Ibadan postgraduate medicine, 14(1), 6-12.

[5]. Dragutinovic, N., \& Twisk, D. (2006). The effectiveness of road safety education: A literature review. SWOV Institute for Road Safety Research.

[6]. Cuenen, A., Brijs, K., Brijs, T., Van Vlierden, K., Daniels, S., \& Wets, G. (2016). Effect evaluation of a road safety education program based on victim testimonials in high schools in Belgium. Accident Analysis \& Prevention, 94, 18-27. https://doi.org/10.1016/j.aap.2016.05.006 
[7]. Riaz, M. S., Cuenen, A., Dhondt, S., Craps, H., Janssens, D., Wets, G., ... \& Brijs, K. (2019). Evaluation of a road safety education program based on driving under influence and traffic risks for higher secondary school students in Belgium. Safety, 5(2), 34. https://doi.org/10.3390/safety5020034

[8]. Choi, N. G., DiNitto, D. M., \& Marti, C. N. (2016). Risk factors for self-reported driving under the influence of alcohol and/or illicit drugs among older adults. The Gerontologist, 56(2), 282-291. https://doi.org/10.1093/geront/gnu070

[9]. Zhang, G., Yau, K. K., \& Gong, X. (2014). Traffic violations in Guangdong Province of China: speeding and drunk driving. Accident Analysis \& Prevention, 64, 30-40. https://doi.org/10.1016/j.aap.2013.11.002

[10]. Knight, P. J., Iverson, D., \& Harris, M. F. (2012). Early driving experience and influence on risk perception in young rural people. Accident Analysis \& Prevention, 45, 775-781. https://doi.org/10.1016/j.aap.2011.10.005

[11]. Constantinou, E., Panayiotou, G., Konstantinou, N., Loutsiou-Ladd, A., \& Kapardis, A. (2011). Risky and aggressive driving in young adults: Personality matters. Accident Analysis \& Prevention, 43(4), 13231331. https://doi.org/10.1016/j.aap.2011.02.002

[12]. DGT. (2015). Anuario estadístico de accidentes, año 2014. Dirección General de Tráfico. Madrid.

Retrieved from:

https://www.dgt.es/Galerias/seguridadvial/estadisticas-e-indicadores/publicaciones/anuarioestadistico-de-accidentes/anuario-accidentes-2014.pdf [accessed: 07 May 2021].

[13]. Europea, U. (2002). Libro blanco: la política europea de transportes de cara al 2010: la hora de la verdad. Retrieved from:

https:/ec.europa.eu/transport/sites/default/files/themes/ strategies/doc/2001_white_paper/lb_texte_complet_es. pdf [accessed: 10 May 2021].

[14]. Useche, S., Alonso, F., Montoro, L., \& Garrigós, L. (2019). More aware, more protected: a cross-sectional study on road safety skills predicting the use of passive safety elements among Spanish teenagers. BMJ open, 9(11), e035007.

https://doi.org/10.1136/bmjopen-2019-035007

[15]. Pourabdian, S., Lotfi, S., Yazdanirad, S., Golshiri, P., \& Hassanzadeh, A. (2021). An Evaluation of the Relationship between Mental Disorders and Driving Accidents among Truck Drivers. International journal of preventive medicine, 12, 74 . https://doi.org/ 10.4103/ijpvm.IJPVM $443 \quad 18$

[16]. Assailly, J. P. (2017). Road safety education: What works?. Patient education and counseling, 100, S24S29. https://doi.org/10.1016/j.pec.2015.10.017

[17]. NZTA. (2013). Road safety resources for secondary school communities. Auckland: New Zealand Transport Agency. Retrieved from: https://education.nzta.govt.nz/assets/Educationportal/Teacher-resources/School-policy-andpractices/Road-map-Road-safety-resources-forsecondary-school-v4.pdf [accessed: 10 May 2021].
[18]. Van Schagen, I., \& Rothengatter, T. (1997). Classroom instruction versus roadside training in traffic safety education. Journal of applied developmental psychology, 18(2), 283-292. https://doi.org/10.1016/S0193-3973(97)90042-3

[19]. Taubman-Ben-Ari, O. (2015). Parents' perceptions of the family climate for road safety. Accident Analysis \& Prevention, 74, 157-161. https://doi.org/10.1016/j.aap.2014.10.023

[20]. Rothman, L., Buliung, R., To, T., Macarthur, C., Macpherson, A., \& Howard, A. (2015). Associations between parents' perception of traffic danger, the built environment and walking to school. Journal of Transport \& Health, 2(3), 327-335. https://doi.org/10.1016/j.jth.2015.05.004

[21]. Meyer, S., Sagberg, F., \& Torquato, R. (2014). Traffic hazard perception among children. Transportation research part $F$ : traffic psychology and behaviour, 26, 190-198. https://doi.org/10.1016/j.trf.2014.07.007

[22]. Bates, L., Watson, B., \& King, M. J. (2014). The role of parents and non-parents in the supervision of learner drivers in Australia. Accident Analysis \& Prevention, 70, 40-45. https://doi.org/10.1016/j.aap.2014.03.004

[23]. Brooks-Russell, A., Simons-Morton, B., \& Ehsani, J. (2014). Parents are the key to improving teen driving safety. Journal of adolescent health, 55(5), 600-601. https://doi.org/10.1016/j.jadohealth.2014.08.008

[24]. Twisk, D. A., Vlakveld, W. P., Commandeur, J. J., Shope, J. T., \& Kok, G. (2014). Five road safety education programmes for young adolescent pedestrians and cyclists: A multi-programme evaluation in a field setting. Accident Analysis \& Prevention, 66, 55-61. https://doi.org/10.1016/j.aap.2014.01.002

[25]. DTMR. (2009). A guide to evaluating road safety education programs for young adults, November 2009. Department of Transport and Main Roads. Queensland.

[26]. Twisk, D., Vlakveld, W., Mesken, J., Shope, J. T., \& Kok, G. (2013). Inexperience and risky decisions of young adolescents, as pedestrians and cyclists, in interactions with lorries, and the effects of competency versus awareness education. Accident Analysis \& Prevention, 55, 219-225. https://doi.org/10.1016/j.aap.2013.02.038

[27]. Markl, M. (2016). Effectiveness of road safety educational program for pre-drivers about DUI: practical implication of the TPB in developing new preventive program in Slovenia. Transportation research procedia, 14, 3829-3838. https://doi.org/10.1016/j.trpro.2016.05.468

[28]. Alicandri, E., Hutton, P., Chrysler, S. T., Depue, L., Glassman, H., Granda, T. M., ... \& Warhoftig, B. (2008). Improving safety and mobility for older road users in Australia and Japan (No. FHWA-PL-09-001). United States. Federal Highway Administration. Office of International Programs. 
TEM Journal. Volume 10, Issue 4, Pages 1509-1519, ISSN 2217-8309, DOI: 10.18421/TEM104-03, November 2021.

[29]. RST. (2010). Older Road Users: A literature review and exploratory analysis of fatalities and serious injury collisions in relation to older road users: Implications for education, engineering and enforcement initiatives. Camborne: Road Safety Team. Retrieved from: https://www.roadsafetyknowledgecentre.org.uk/rskc939/ [accessed: 20 May 2021].

[30]. RACV. (2001). The effectiveness of driver training as a road safety measure. Melbourne: Royal Automobile Club of Victoria. Retrieved from:

https:/www.nrspp.org.au/resources/the-effectivenessof-driver-training-as-a-road-safety-measure-a-reviewof-the-literature/ [accessed: 25 May 2021].
[31]. Kitamura, Y. (2014). The possibility of holistic safety education in Japan: from the perspective of education for sustainable development (ESD). IATSS research, 38(1), 40-47. https://doi.org/10.1016/j.iatssr.2014.05.004

[32]. Razavi, T. (2001). Self-Report Measures: An Overview of Concerns and Limitations of Questionnaire Use in Occupational Stress Research. University of Southampton-Department of Accounting and Management Science Papers, (01175). 